\title{
Örtük Program, Resmi Program ve Okul Dışı Etmenlerin Değerleri Kazandırma Etkililiğinin İncelenmesi*
}

\author{
Derya KAVGAOĞLU**, Seval FER ${ }^{* * *}$
}

Öz

Bu araştırmanın amacı örtük programın, resmi programın ve okul dışı etmenlerin (aile, medya, okul dışı sosyal çevre) değerleri kazandırma etkililiğini öğretmen ve öğrenci görüşlerine göre incelemektir. Betimsel araştırma kapsamındaki genel tarama modeli uygulanan araştırmanın çalışma grubunu 155 öğretmen ve 740 öğrenci oluşturmuştur. Verilerin analizi için Manova (çok değişkenli varyans analizi) ve Two-way Anova (iki yönlü varyans analizi) yapılmıştır. Araștırmayla hem öğretmen hem de öğrenci görüşlerine göre değerlerin kazanılmasında en etkili faktör okul dışı etmenler (aile, medya-sosyal çevre) olarak belirlenmiştir. Örtük program özellikle kişisel-evrensel değerlerin kazanılmasında resmi programın önüne geçmiștir. Değerlerin kazanılmasında öğrenciler örtük programı resmi programdan daha etkili görürken öğretmenler resmi programı örtük programdan daha etkili bulmuşlardır.

Anahtar Kelimeler: Örtük Program, Resmi Program, Değerler, Program Değerlendirme, Öğretim Tasarımı, Eğitim Felsefesi, Öğrenme.

\section{Analysis of Hidden Curriculum, School Curricula and Out-of-School-Sources About Gaining Values}

\begin{abstract}
The goal of this investigation was to evaluate of hidden curriculum, school curricula and out-of-school-sources (family, media, out of school social life) about gaining values according to teachers and students opinion. Descriptive research with a survey model was used in this research. Sample group contained 155 teachers and 740 students.

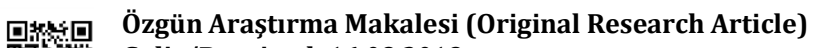

Geliş/Received: 16.08 .2018

Kabul/Accepted: 24.03 .2020

DOI: https://dx.doi.org/10.17336/igusbd.450338

* Bu çalıșma, Yıldız Teknik Üniversitesi. Eğitim Fakültesi, Eğitim Programları ve Öğretim Anabilim Dalı'nda, Prof. Dr. Seval FER danışmanlığında hazırlanan ve 29.06.2009 tarihinde kabul edilen “İlköğretim Programlarının Örtük Programın ve Okul Dışı Etmenlerin Değerleri Kazandırma Etkililiğinin 8. Sınıf İlköğretim Öğrencilerinin ve Öğretmenlerinin Görüşlerine Göre İncelenmesi” başlıklı yüksek lisans tez çalışmasından üretilmiştir. 8-10 Eylül 2011 tarihlerinde Burdur Mehmet Akif Ersoy Üniversitesinde yapılan 20. Ulusal Eğitim Bilimleri Kurultayı'nda sözlü bidiri olarak sunulmuştur.

** Dr. Öğr. Üyesi, İstanbul Gelişim Üniversitesi, Sağlık Bilimleri Yüksekokulu, Sosyal Hizmetler Bölümü, İstanbul, Türkiye, E-posta: dkavgaoglu@gelisim.edu.tr ORCID http://orcid.org/00000001-5926-3081

*** Prof. Dr., Hacettepe Üniversitesi, Eğitim Fakültesi, Eğitim Bilimleri Bölümü, Ankara, Türkiye, E-posta: seval.fer@gmail.com ORCID http://orcid.org/0000-0002-9577-2120
} 
Multiple variable variance analysis (Manova) and two-way variance analysis (Two-way Anova) were used to analyze data. With this investigation, it was found by students and teachers opinion, out-of-school sources (family, media and social life) were the most effective factor about gaining values. Moreover, hidden curriculum was more effective than curricula especially gaining of personal-universal values. The findings showed that hidden curriculum was more effective than curricula according to students on the other hand, curricula was more effective than hidden curriculum according to teachers views.

Keywords: Hidden Curriculum, Curricula, Values, Curriculum Evaluation, Instructional Design, Philosophy of Education, Learning.

\section{Giriş}

Ders kazanımlarına odaklanmış ve öğrencileri yalnızca sahip oldukları bilginin seviyesiyle ölçen bir eğitim, sağlıklı karakter gelişimini ve ahlaki yeterliliği ihmal edebileceğinden, öğrenenlere sahip olacakları bilgilerle insanlık için ve insanca değer üretme yetkinliğini kazandırma kabiliyetinden de uzak olacaktır. Bu durum uzun vadede iş gören fakat değer bilmez profillerin ortaya çımasına neden olabilecektir. Oysa eğitimli insan, sadece zihinsel performansı ve kapasitesiyle değil, yansıttığı değer yargılarıyla da yaşadığı toplumun aynası durumundadır. Bu nedenle eğitimin rotasını belirleyen program geliştirme etkinlikleri de öğrenenin sadece entelektüel bir değer değil aynı zamanda sosyal bir değer olduğu kabulüyle ve insan olma mantığı üzerinde temellenmelidir.

Günümüzde cinayet, gasp, hırsızlık, yolsuzluk, hak ihlali haberlerinin sayıları gittikçe artmaktadır. Yapılan araștırmalar gençler arasında madde bağımlılığı, depresyon, intihara teşebbüs, saldırganlık gibi istenmeyen pek çok davranışın gün geçtikçe arttığını gösterir niteliktedir. Bütün bunlar toplumsal değer yargılarının yozlaşmaya başladığının da ifadesidir.

İnsanın 'değeri' ve 'değerleriyle' ilgili bir erozyonun yaşandığı çağımızda; bu erozyonun yarattığı önemli kayıplarla girdiğimiz 21. yüzyılda her zamankinden çok daha fazla bu değerlere sahip çıkılmalıdır (Kale, 2004, s.9). Ornstein ve Hunkins (2017), 21. yüzyılın, şiddet eğilimleriyle, ekonomik istikrarsızlıklarıyla, doğal felaketleriyle kaos özelliği taşıdığını ifade eder; insanın neden olduğu bu kargaşanın ve belirsizliğin çözümünde çıkış noktası olarak değerler eğitiminin önemine işaret eder. Bu düşünceyi 11 Eylül saldırılarını örnek göstererek tartışır. Bu saldırıların, eğitimde köklü bir değişime gitmeye karar vermek için bir milat kabul edilmesi gerektiğini, çözümün ise ahlaki ve manevi değerlerin eğitimiyle mümkün olacağını vurgular.

Değerler insan davranışlarına yön veren kriterlerdir ve tüm öğrenilmiş insan davranışlarının temelinde değerler vardır. İnsan gerçek dünyada bu değerleri benimseyip yaşatarak doğaya anlam yükler ve evreni değerler evreni haline getirir (Cevizci, 2008, s.327; Sönmez, 2008, s.19; Tunalı 2008, s.132). Erden (2005), kişiden kişiye, toplumdan topluma farklılık gösterse de bazı ahlaki, milli, dini değerlerin çoğunluk tarafından kabul gördüğünü vurgular. Gardner (2006) da 'gerçeklik', 'güzellik', 'ahlak' gibi değerlere odaklanır ve insanın ancak bu genel geçer değerler üzerinde temellenen bir eğitimle dünyayı kavrayıp geliștirme çabası içine girebileceğini vurgular.

Türk Milli Eğitiminin ve okulların genel hedeflerinde birçok değer ifadesi olduğu görülmektedir. Okullar var olduğu sürece değer eğitimi olacaktır. Çünkü okul yapısı itibarıyla zaten değer kazandırır (Akbaş, 2007, s.676). İlköğretim Genel Müdürlüğü resmi internet sitesinde (IOGM, 2009) değerler, çoğunluk tarafından toplumun işleyişini, varlığını, birliğini, devamını sağlamak ve sürdürmek için doğruluğu ve gerekliliği kabul edilen amaç, düşünce, inanç veya temel ahlaki ilke olarak ele alınmıştır. Yakın zamanda 
güncellenerek yeniden yayımlanan temel eğitim programlarında ise değerler öğretim programlarının perspektifini oluşturan ilkeler toplamı olarak ifade edilmiş ve öğretim programlarının herbirinde ve herbir biriminde yer verildiği ifade edilen kök değerler (yardımseverlik adalet, vatanseverlik, sorumluluk, sevgi, saygı, öz denetim, dürüstlük, dostluk, sabır) vurgulanmıştır (IOGM, 2018, s.4). Ancak, öğretim programlarında kazanım listelerine yer vermek değerlere sahip çlkılıyor demek için yeterli değildir. Önemli olan bu yolda kontrollü ve sürekli bir çaba harcayarak kazanımların hangi yollarla ne kadar kazanılabildiğinin takip edilmesidir. Bu sayede yeni kuşakların 'değersiz' yetişmesinin önüne geçilebilir.

Erden (2005) toplumdaki en önemli sosyal kontrol aracı olarak eğitim kurumlarını göstererek çoğunluk tarafından kabul edilen değerlerin, tutumların ve normarın çocuklar ve gençler tarafından bu kurumlar yoluyla kontrollü ve planlı bir şekilde kazanılabildiğinin altını çizer. Bununla birlikte bu sosyal kontrol araçlarının ekonomi, politika, din ve aile kurumlarının talep ettiği değer ve normlardan tamamen tamamen bağımsız olamayacağını da vurgular. Benzer düşünceyi Apple (2012), Bowles ve Gintis (2011), Anyon (1984) da okullarda ekonominin, kültürün ve baskın ideolojinin yeniden üretildiği ifade ederek tartışır. Dreeben (2002) de öğrencilerin okullarda ailelerinden öğrenemedikleri pek çok norm ve yetkinliği öğrenebildiklerini, toplum tarafından önemli olduğu kabul edilen değer, norm ve görüşleri kazanarak sosyal hayata hazırlandıklarını ifade eder. Wren (1999) okul kültürüne dikkat çekerek değerlerin kazanılmasında okul kurallarını, gelenek haline getirilmiş etkinlikleri, resmi-dini törenleri vurgular. Bacanlı (2006) da değerlerin sadece sınıf içi uygulamalarla değil, okulda ders saatleri dışında, program dışı aktivitelerle, okulun koridorlarında, bahçesinde, okul arkadaşlarıyla, okuldaki diğer öğretmenlerle ve hatta okul yöneticileriyle olan sosyal etkileşimle de kazanılabileceğini belirtir.

Eğitimin sadece ders saatleriyle sınırlandırılmış bir zaman dilimi içinde sınıfta gerçekleșen bir etkinlik olduğunu düşünmek doğru değildir. Erdem'in (2006) de ifade ettiği gibi insan hayatın her aşamasında eğitime tabidir ve sadece okulda değil sokakta, camide, askerde, ailede, arkadaş grubunda kısaca her ortamda öğrenebilir. Yani, insan yaşadığı her yerde, yaşamı boyunca eğitimin öznesi olabilir. Bu eğitim etkinliklerinin önemli bir kısmı örtük olarak oluşur. Çoğunlukla bu yolla öğrenme daha kolay gerçekleşir ve kalıcı izler bırakır. Son derece masum nedenlerle açılan muhtelif yurtların ve kursların uyguladıkları örtük faaliyetlerle devletin eğitimle ulaşamadığı veya ulaşmakta yetersiz kaldığı gençleri ele geçirerek ideolojileri doğrultusunda kullanmaları buna örnek olarak gösterilebilir. Benzer şekilde eğitilemeyen gençlerin belli ideolojileri körü körüne sahiplenecek birer militan, piyon haline getirilmeleri, yeni neslin medyanın empoze ettiği genel geçer değerleri edilgen bir şekilde benimseyerek yetişmeleri gibi örnekler eğitimin örtük olarak oluşan kısmının ne kadar etkili olduğunu göstermektedir. Bu çalıșmanın çıkış noktası da öncelikle bu fikirler üzerinde temellenmiștir. Eğitimin çoğunlukla değerlerin kazanılmasına yönelik ihmal edilen ișlevine odaklanılmış, değerlerin her yerde ve her fırsatta öğrenilebileceği düşüncesinden yola çıkılmış yeni kuşakların değerleri hangi yollarla en etkili șekilde kazanabilecekleri sorusuna cevap aranmıştır.

Eğitimin okul binasında başlayıp okul dışına kadar taşan, örtük olarak oluşan ve değerlerin kazanılmasında çoğu zaman resmi programdan daha etkili olabilen kısmı da tıpkı resmi program gibi tüm boyutlarıyla örtük program kapsamında planlanabilmelidir. Literatürde örtük program kavramı 1968'den beri yer almaktadır. Kavram, literatürde genel geçer tek bir tanımla ifade edilmemektedir. Jackson (1991), Dreeben (2002) ve Hemmings'e (2000) göre örtük program 'öğrencilerin, eğitim kurumlarının norm ve değerlerine, düzene uyum sağlama süreci'dir. Doll (1995) ve Bacanlı’ya (2006) göre örtük program 'kendisini toplumca kabul görmeyen ve beklenmeyen öğrenme sonuçlariyla gösteren program'dır. Apple (2012), Anyon (1984), Bowles ve Gintis (2011), Çınar 
(2003), Giroux (2001) ve Lynch'in (1989) bakış açısıyla örtük program, 'resmi programda belirtilmemiș, etkin olan toplumsal-siyasal görüş ve değerlerin okullarda öğretmen ve yöneticiler kanalıyla örtük bir şekilde verilmesi' olarak ifade edilir. Bununla birlikte Giroux (2001) sosyal yapıyı oluşturan önemli bir işleyiş olarak kabul ettiği eğitimin temelde fikirlerin özgürleşmesi süreci olduğunu ve baskın ideolojilerle şekillendirilmesinin bu temel amaçla çelişki yaratacağını, bu çelişkinin bir sonucu olarak da eğitimin öznesi durumundaki kitlelerin direnç göstermeye başlayacağını ifade eder. Wren (2001) ise örtük programı 'okul kültürünü ve organizasyon iklimini etkileyen değerlerin oluştuğu süreç' şeklinde tanımlar. Yüksel (2004) örtük programın (1) okulun örgütsel ve idari araç düzenlemeleriyle, (2) sınıf iklimiyle, (3) okul çevre etkileşimiyle değerlerin kazanılmasını sağladığını ifade eder. Erdoğan (2008) örtük programın okul dışına taşan kısmına işaret eder; bilgi, beceri, değer ve tutumların okul dışı etkileşimlerle de kazanıldığını vurgular. Benzer şekilde Barbour, Roberts-King, Stites ve Scully (2018), çocukların ailelerinden, akran gruplarının tutumlarından, medyadan, toplumdan, geleneklerden de etkilendiğini dolayısıyla eğitimden yeterince verim alabilmek için okulun dışında yer alan bu etkilenmelerin de yönetilmesi gerektiğini vurgular.

Örtük program kavramı Türkiye'de 2009'a kadar az sayıda araştırmaya konu olabilmiştir. Örneğin; Helvacıoğlu (1994) ile Bağlı ve Esen (2002) tarafından yapılan araştırmalar örtük programın ders kitapları aracılığıyla cinsiyetçi değerleri aktardığını ortaya çıkarır niteliktedir. Arıkan (2004) da örtük programın cinsiyet ve toplumsal sınıflara ilişkin değerleri aşıladığını belirlemiștir. Doğanay ve Sarı (2004) ile Sarı (2007) tarafından, örtük programın okullarda antidemokratik değerlerin kazanılmasına sebep olduğu ortaya çıkarılmıştır. Temiz'in (2007) araştırması, medyadaki örtük programın çocukların davranışlarını, tutumlarını, hayallerini şekillendirdiğini göstermektedir. Kavak, Tufan ve Demirelli (2006) tarafindan yapılan araştırmada, gazetelerin haber yansıtma şeklinin, okuyucuyu, habere ilişkin olumlu veya olumsuz tutum sergileme bakımından örtük olarak yönlendirdiği tespit edilmiştir. Ulusoy (2007), Evin ve Kafadar (2004) ile Şen (2008) tarafından yapılan araştırmalarda, öğretim programlarının ve ders kitaplarının ağırlıklı olarak ulusal değerleri aktardığı sonucuna ulaşılmıştır. Tuncel (2008) tarafından yapılan araştırmayla örtük programın, hissedilen öğretmen beklentileri üzerinden öğrencilerin paylaşma, dayanışma, benlik saygısı ve metabilişsel becerilerini etkilediği bulgulanmıștır. Örtük program konusunda halihazırda YÖK Tez Merkezine kayıtlı on altısı doktora, on dokuzu yüksek lisans olmak üzere otuz beş lisansüstü tez bulunmaktadır. Bunların otuzu 2009 sonrasında yazılmış tezlerdir. Bu araştırmaların önemli bir kısmı sınıf içi iletişimde örtük programın gözlenebilir şekilde öğretmen ve öğrenci davranışlarına nasıl yansıdı̆̆ı, istenmeyen öğrenci davranışlarını bastırmak üzere nasıl kullanılabileceği gibi örtük programın sınıf iklimine yansıyan kısmının ve sıklıkla öğrenci görüşüne başvurularak değerlendirilmesi üzerinde yoğunlaşmaktadır (Kesici, 2010; Adıay, 2011; Akbulut, 2011; Başar, 2011; Filiz, 2011; Sezen, 2011; Çengel, 2013; Fidan, 2013; Tor, 2015; Yıldırım, 2015; Akbulut, 2016; Aktaş, 2016; Akçakoca, 2018; Özaslan, 2019). Araştırmaların bir kısmı ise örtük programı değer, tutum, beceri ve yetkinlik kazandırma boyutuyla ele almıștır (Serhatlığlu, 2012; Demir, 2013; Yıldırım, 2013; Baydilek, 2015; Boztaş, 2015; Coşkun, 2016; Hatipoğlu, 2018). Bununla birlikte örtük programı spesifik öğrenme mesajları verme açısından okul veya ders öğretim programlarının bir parçası olarak inceleyen araştırmalar da bulunmaktadır (Aydeniz, 2017; Saldıray, 2017; Tanrıverdi, 2017; Gün, 2018; Yıldırım, 2018; Girayhan, 2019; Koyuncu, 2019; Şenyüksel, 2019). Ayrıca son dönemde sosyal medyayı, öğretmenöğrenci etkileşimi bağlamında, okul dışı öğrenmeleri destekleyen örtük program aracı olarak inceleyen bir araştırmaya da rastlanmıştır (Demir, 2018).

Örtük program konusunda yurt dışında yapılan araştırmalar ise daha ziyade örtük programın ideolojik, sosyal ve politik yönlerini belirlemeye odaklanmıștır. Örneğin örtük 
program kavramını literatüre taşıyan ilk isim olan Jackson (1991) araştırmasında sınıflarda oluşan örtük programın uyum temelli davranışlar ve tutumlar kazandırdığı bulgusuna ulaşmıştır. Hemmings'in (2000) araştırması örtük programın ırkçılık, cinsiyetçilik, düşmanlık kültürünü yarattığını ortaya çıkarır niteliktedir. Tietz (2007), ders kitaplarının cinsiyetçi öğeleri örtük olarak aktardığını belirlemiștir. Sambell ve McDowell (1998) ile Ahola (2000) tarafından yapılan araștırmalar, örtük programın, uygulanan öğretim programları ile kullanılan öğretim yöntem ve teknikleri aracılığıyla, okul ve toplum hayatına uyum sağlama sürecinde, istendik ve istenmedik değerlerin kazanılmasında etkili olduğu sonucuna ulaşır. Ziebertz'in (2007) değerlere yönelik olarak yaptığı araștırma, gençliğin hakim olan benmerkezci dünya görüşünü örtük olarak benimsediğini ortaya çıkarır niteliktedir. Smith ve Smith (2008) ilerleyen yaşa ve eğitim düzeyine bağlı olarak bilgi, beceri, tutum ve değer kazanma sürecinde okul dışı öğrenme yollarına (medya, sosyal çevre vb.) yöneliș eğiliminin yükseldiğini belirlemiștir. Lempp ve Seale'nin (2004) araştırmasında okul kültürünün örtük programla şekillendiği ortaya çıkarılmıştır. Castello (2001) ile Gair ve Mullins (2001) de toplumsal, siyasi, ekonomik hayatla okul hayatını ilişkilendirmiş ve örtük programın okullarda sınıfsal eşitsizliği, ırk ve cinsiyet ayrımını tetiklediği sonucuna ulaşmışlardır.

Yukarıda kısaca yer verilen örtük program araștırmalarından çoğunun nitel olduğu, dolayısıyla çok küçük bir grup üzerinde çalışıldığı ve bulguların genellenme engelinin olduğu görülmüștür. Ayrıca, örtük program hakkında yurt içinde ve yurt dışında çok az sayıda araştırma yapılmış, mevcutların çoğu da örtük programı sadece kuramsal açıdan tartışmıştır. Bir diğer önemli nokta yapılan araştırmaların örtük programı, etkili fakat kontrol edilmediği için de olumsuz pek çok değerin rastlantısal olarak kazanılmasına ve edilgen olarak tüketilmesine neden olan bir araç olarak ele almasıdır. $\mathrm{Bu}$ makalede ise diğerlerinden farklı olarak örtük programa ilişkin panoramik bir manzara sunulmuştur. Örtük öğrenmeler değer kazanma yollarına göre sınıflandırılarak bu yolların doğru planlandığı takdirde etkili birer örtük öğrenme aracı olarak kullanılabileceği ortaya çıkarılmıştır.

$\mathrm{Bu}$ kuramsal zemin çerçevesinde araştırmanın amacı "8. sınıf öğrencilerinin ve öğretmenlerinin görüsslerine göre örtük programın, resmi programın ve okul dışı etmenlerin değerleri kazandırma etkililiğini" incelemek șeklinde belirlenmiştir. Bu amaç doğrultusunda şu iki soruya yanıt aranmıştır:

(1) Öğrencilerin, öğretim programlarında (1-8. sınıf) yer alan değerleri (kişiselevrensel, ulusal) kazanma etkililiği, bu değerleri kazanma yolları (resmi program, örtük program, okul dışı etmenler) ile öğretmen ve öğrenci görüşlerine göre anlamlı bir farklılık göstermekte midir?

(2) Öğrencilerin değerleri kazandığı yolların (resmi program, örtük program, aile ortamı, akraba ortamı, medya-sosyal çevre) etkililiği öğretmen ve öğrenci görüşleri açısından anlamlı bir farklılık göstermekte midir? Değerlerin kazanılmasında etkili olduğu belirlenen yolların, özellikle program geliştirme uzmanlarının örtük öğrenmeleri kılavuzlama çabasına yardımcı olabileceği düşünülmektedir.

\section{Yöntem}

\section{Araştırmanın Modeli ve Çalışma Grubu}

Araştırma betimsel araştırma kapsamındaki genel tarama modeliyle yapılmıștır. Seçilen araştırma konusunu, kendi ortamında, olduğu gibi tanımlamaya firsat verdiği için bu model tercih edilmiştir (Karasar, 2005). Araştırmanın çalıșma grubu, 2008-2009 öğretim yılında İstanbul ilinin Avrupa yakasında bulunan altı ilçesindeki (Avcılar, Bahçelievler, Bakırköy, Gaziosmanpaşa, Güngören, Zeytinburnu) resmi öğretim kurumlarında öğrenim gören 740 sekizinci sınıf öğrencisinden ve bu okullarda görev 
yapan 155 öğretmenden oluşmuştur. Çalışma grubu oluşturulurken, araştırma problemine uygun olarak hazırlanan anketin kontrollü ve sağlıklı olarak doldurulması ve veri kaybı yaşanmaması için her birinde süreci kontrol edecek gönüllü öğretmenlerin olduğu okullar tercih edilmiştir.

\section{Veri Toplama Araçlarının Hazırlanması ve Pilot Uygulama}

$\mathrm{Bu}$ araștırmanın verileri Fer ve Kuş (2009) tarafından geliştirilen 'İlköğretim Programlarında Yer Alan Değerleri Kazanma Yolları Anketi’ ile toplanmıștır. Anket, öğrenci ve öğretmen görüşlerini almaya yönelik olarak hazırlanmış aynı maddeleri içeren iki formdan oluşmuştur. Her iki formda da Tablo 1'de görüleceği gibi 'Değerler' ve 'Değerleri kazanma yolları'na yönelik iki boyut yer almıştır.

Tablo 1: Anketin Boyutlarına Göre Cevap Aranan Sorular

\begin{tabular}{|l|l|}
\hline Boyutlar & Cevap Aranan Sorular \\
\hline $\begin{array}{l}\text { I.Boyut: } \\
\text { Değerler Boyutu }\end{array}$ & $\begin{array}{l}\text { Öğrencilerin, öğretim programlarında (1-8. sınıf) yer alan kişisel- } \\
\text { evrensel, ulusal değerleri kazanma etkililiği, değerleri kazanma } \\
\text { yollarına (okul dışı etmenler, örtük program, resmi program) ve } \\
\text { öğretmen ile öğrenci görüşlerine göre anlamlı bir farklılık } \\
\text { göstermekte midir? }\end{array}$ \\
\hline $\begin{array}{l}\text { Ö. Boyut: } \\
\begin{array}{l}\text { Değerleri } \\
\text { Kazanma Yolları } \\
\text { Boyutu }\end{array}\end{array}$ & $\begin{array}{l}\text { ortamı, medya-sosyal çevre, örtük program, resmi program) } \\
\text { etkililiğg, öğretmen ile öğrenci görüşlerine göre anlamlı bir } \\
\text { farklılık göstermekte midir? }\end{array}$ \\
\hline
\end{tabular}

Tablo 1'de görüldüğü gibi anketin ilk boyutu araştırmanın birinci sorusunu, ikinci boyutu ise araştırmanın ikinci sorusunu cevaplayacak şekilde tasarlanmıștır. Anketin ilk boyutu hazırlanırken, hangi değerlerin kazanıldığını belirlemek üzere, 2005 ilköğretim programlarında zorunlu dersler kapsamında açıç̧a yer alan değer ifadeleri tespit edilmiștir. Anketin ikinci boyutunda ise değerlerin hangi yollarla kazanıldığını belirlemek üzere ilgili literatür taranmıștır. Hazırlanan anket taslağı, yedisi Yıldız Teknik Üniversitesi öğretim üyesi sekiz konu alanı uzmanına sunulmuş, en az beș uzmanın ortak fikriyle önerilen değişiklikler esas alınarak yeniden düzenlenmiş ve pilot uygulamaya geçilmiştir. Zeytinburnu Haluk Ündeğer İlköğretim Okulu'nda, 15 öğretmen ve 10 öğrencinin katılımıyla gerçekleşen pilot uygulamada anketin anlaşılırlığı test edilmiş, sonrasında gerekli düzenlemeler yapılarak ilk boyutta 53, ikinci boyutta 52 olmak üzere toplam 105 maddeden oluşan son hali verilerek uygulamaya geçilmiştir.

\section{Verilerin Toplanması}

Hazırlanan anket 2008-2009 öğretim yılında gönüllülük ilkesine göre sekizinci sınıf öğretmenlerine ve öğrencilerine uygulanmıştır. Uygulama öncesinde her okulda uygulamayı gerçekleștirecek öğretmenlere ölçme aracı hakkında bilgi verilmiştir. Anketin soruları üçlü likert tipinde olup, cevap seçenekleri (1) etkisiz, (2) etkili, (3) çok etkili biçimindedir. Katılımcıların anketi doldurma süresi 20-40 dakika arasında değișmiştir. Geçerlik ve güvenilirlik çalışması Șencan'ın (2005) ifade ettiği gibi uygulama sonuçlarına dayalı olarak yapılmıștır. 


\section{Geçerlik ve Güvenilirlik Çalışması}

Anketin yapı geçerliliği için SPSS 15.0 programı kullanılarak faktör analizi yapılmıştır. Büyüköztürk'e (2018) göre verilerin faktör analizi için uygunluğu KMO katsayısı ve Barlett Sphericity testi ile incelenebilir. KMO'nun 0.60'tan yüksek, Barlett testinin anlamlı çıkması verilerin faktör analizi için uygunluğunu gösterir. Faktör analizinden önce sırasıyla KMO (Kaiser-Meyer-Olkin) örneklem yeterlilik testi yapılmış, bu değer öğrenci anketinin ilk boyutu için 0.953, ikinci boyutu için 0.859; öğretmen anketinin ilk boyutu için 0.937, ikinci boyutu için 0.910 olarak tespit edilmiştir. Ardından Barlett Küresellik testi yapılmış ve bu değer de öğrenci anketinin ilk boyutu için 12850.87, s.d. $=1081, p=.00$, ikinci boyutu için 11590.77 , s.d. $=1081, p=.00$; öğretmen anketinin ilk boyutu için 5269.75 , s.d.=630, p=.00, ikinci boyutu için 4141.75, s.d.=946, p=.00 olarak belirlenmiştir.

Faktör analizinde aynı yapıyı ölçmeyen maddelerin ayıklanması işleminde ise yine Büyüköztürk'ün ifade ettiği gibi; maddelerin yer aldıkları faktördeki yük değerinin 0.30 ve üzerinde olması, yüksek iki yük değeri arasındaki farkın en az 0.10 olması ve maddelerin ortak faktör varyanslarının 1'e yakın olması ölçütleri dikkate alınmıştır. Buna göre öğrenci görüşleri anketi bu ölçütlere uymayan on bir maddenin atılmasıyla doksan dört maddeye; öğretmen görüşleri anketi ise bu ölçütlere uymayan yirmi beş maddenin atılmasıyla seksen maddeye inmiştir. Faktör analizinde mevcut değişkenlerin kaç önemli faktörü ya da yapıyı ölçtüğüne karar vermek için ise faktör özdeğerinin 2'den büyük olması, faktörlerin toplam varyansı açıklama yüzdesi ve Scree grafiğindeki yüksek ivmeli düşüşlerin sonlandığı nokta esas alınmıștır. Araştırmada hem öğretmen hem öğrenci anketlerinin değerler boyutunda faktörler arası ilişkinin yüksek olması nedeniyle eğik döndürme (Promax) tekniği, değerleri kazanma yolları boyutunda ise faktörler arası iliş̧inin düşük olması nedeniyle dik döndürme (Varimax) tekniği kullanılmıştır. Her iki ankette de bu kriterler esas alınarak iki temel boyut altında yedi faktör tespit edilmiştir. $\mathrm{Bu}$ faktörler ilk boyutta kişisel-evrensel ve ulusal değerler; ikinci boyutta da aile ortamı, akraba ortamı, medya-sosyal çevre, örtük program, resmi program olarak ifade edilmiştir.

Anketin güvenilirlik çalışması için önce içsel tutarlılık hesaplanmıştır. İçsel tutarlılığın ölçümünde en yaygın kullanılan yöntem olan ve Cronbach Alpha olarak da bilinen alfa katsayısında kabul edilebilir değerin en az 0.70 olması arzu edilir (Altunıșık, Coşkun, Bayraktaroğlu \& Yıldırım, 2005, s.114). Her iki ankette tüm boyutlar için bu değerin 0.80-0.97 arasında değiştiği tespit edilmiştir. Anketteki maddelerin benzer davranışları temsil etmede iyi birer ayırt edici olup olmadıklarını tespit etmek için madde-toplam puan korelasyonu hesaplanmıștır. Büyüköztürk (2006), madde-toplam korelasyonu 0.30 ve daha yüksek olan maddelerin bireyleri iyi derecede ayırt ettiğini 0.20-0.30 arasında kalan maddelerin zorunlu görülmesi durumunda ölçeğe alınabileceğini veya maddenin düzeltilmesi gerektiğini, 0.20 'den daha düşük maddelerin ise ölçeğe alınmaması gerektiği ifade eder. Her iki ankette tüm boyutlar için bu değerin 0.32-0.80 arasında değiștiği tespit edilmiştir.

\section{Verilerin Analizi}

Araştırmanın birinci sorusu için Manova (Çok Değişkenli Varyans Analizi), ikinci sorusu için Anova (İki Yönlü Varyans Analizi) tekniği kullanılmıştır. Her alt problemde $\mathrm{H}_{0}$ hipotezi olarak grup ortalamaları arasında fark olmadığı diğer bir ifadeyle grupların ortalamalarının birbirine eşit olduğu, $\mathrm{H}_{1}$ hipotezi olarak da gruplar arası ortalamaların birbirinden farklı olduğu kabul edilmiş ve $\mathrm{p}<0.05$ olduğu durumlarda $\mathrm{H}_{1}$ hipotezi kabul edilerek, $\mathrm{H}_{0}$ hipotezi reddedilmiştir. Her iki araştırma sorusunda da öğretmen ve öğrenci 
görüşlerindeki farkı değerlendirmek üzere grup sayısı üçten az olduğu için post hoc'a gidilemediğinden ilişkisiz örneklem t testi yapılmıștır.

\section{Sonuçlar ve Tartışma}

Araştırmayla ulaşılan sonuçlara göre; okul dıșı etmenler hem öğretmenlerin hem de öğrencilerin görüşlerine göre kişisel-evrensel ve ulusal değerlerin kazanılmasında en etkili faktör olarak belirlenmiştir. Kişisel-evrensel değerlerin kazanılmasında örtük programın, resmi programın önüne geçtiği belirlenmiştir. Okul dışında değer kazanma yollarının etkililiği hem öğretmenlerin hem de öğrencilerin görüşlerine göre sırasıyla aile ortamı, medya-sosyal çevre, akraba ortamı olarak belirlenmiştir. Değerlerin kazanılmasında örtük programın öğrencilere göre resmi programdan daha etkili bir yol olduğu; resmi programın ise öğretmenlere göre örtük programdan daha etkili bir yol olduğu saptanmıştır. Bu sonuçlara yol açan bulgular her bir araştırma sorusuna ilişkin olarak takip eden kısımda tartışılmaktadır. Araştırmanın birinci sorusuna iliş̧in bulgular Tablo 2'de verilmiştir.

Tablo 2: Yollara, Öğretmen ve Öğrenci Görüşlerine Göre Değerleri Kazanma Etkililiğine İlișkin Manova Değerleri

\begin{tabular}{|l|l|l|l|l|l|l|l|}
\hline Etki & & Değer & $\mathrm{F}$ & $\begin{array}{l}\text { Hipotez } \\
\text { sd }\end{array}$ & Hata sd & $\mathrm{p}$ & $\Gamma^{2}$ \\
\hline Öğretmen-Öğrenci & Wilk's lambda & .93 & 97.39 & 2.00 & 2680.00 & .00 & .06 \\
\hline Değer Kazanma Yolları & Wilk's lambda & .94 & 39.40 & 4.00 & 5360.00 & .00 & .02 \\
\hline
\end{tabular}

\section{$\Gamma^{2}$ : Eta Kare}

Tablo 2'den de izleneceği gibi, değer kazanma yollarına $(\lambda=0.94, F(4-5360)=39.40$, $\Gamma 2=0.02, p=0.00, p<0.05)$ ve öğretmen ve öğrenci görüşlerine $(\lambda=0.93, F(2-2680)=97.39$, $\Gamma 2=0.06, \mathrm{p}=0.00, \mathrm{p}<0.05)$ göre değerlerin kazanılma etkililiğinde anlamlı farklılıklar vardır. Öğretmen ve öğrenci görüşleri arasındaki farkın incelenmesi için grup sayısı üçten az olduğundan post hoc yapılamamış, $\mathrm{t}$ testi yapılmıştır. Yapılan $\mathrm{t}$ testi ile hem kişiselevrensel değerlerin $(t=0.73, p=0.00, p<0.05)$ hem de ulusal değerlerin $(t=0.47, p=0.00$, $\mathrm{p}<0.05$ ) kazanılma etkililiğinde öğrenciler lehine anlamlı farklılıklar belirlenmiştir. Farklılığa ilişkin çizgi grafiği Şekil 1'de verilmiştir.
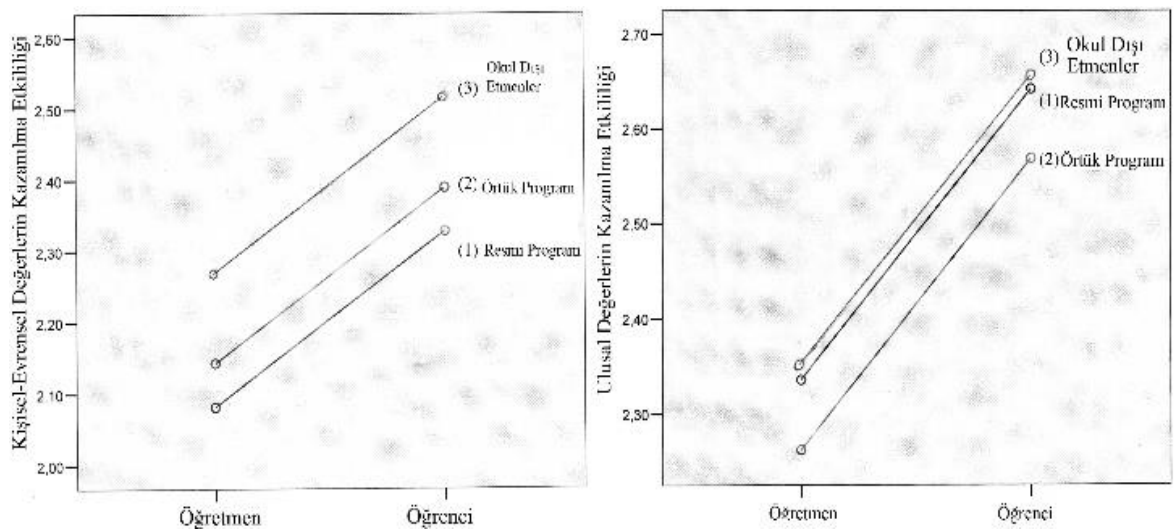

Şekil 1: Kişisel-Evrensel ve Ulusal Değerlerin Kazanılma Etkililiğine İlişkin Öğretmen ve Öğrenci Görüşleri 
Şekil 1'de de görüldüğü gibi hem kișisel-evrensel değerlerin hem de ulusal değerlerin kazanılma etkililiği, öğretmen - öğrenci görüşlerine göre ve değer kazanma yollarına (okul dişı etmenler, örtük program, resmi program) göre farklılaşmıştır. Hem kişisel-evrensel hem de ulusal değerlerin öğrenildiği herbir yol öğrencilerin görüşlerine göre daha etkilidir. Bununla birlikte hem öğretmenler hem de öğrenciler için bu yolların etkililik sıralarının aynı olduğu görülmüştür.

Araştırmanın birinci sorusuna ilişkin dikkati çeken ilk bulgu şudur: Okul dişı etmenler kişisel-evrensel ve ulusal değerlerin kazanılmasında hem öğretmenlerin hem de öğrencilerin görüşleriyle en etkili faktör olarak belirlenmiştir. Buna göre eğitim okul binası dışında da faaliyettedir; öğretmen de öğrenci de bunun farkındadır. Araştırmanın bu bulgusu daha önce Smith ve Smith (2000), Temiz (2007), Kavak vd. (2006), Eldeleklioğlu (2016) tarafından yapılan araștırmaları destekler niteliktedir. Nitekim bu araștırmalar da okul kurumundan bağımsız olarak gerçekleșen öğrenmelerin etkililiğine odaklanmaktadır. Erdoğan'ın (2008) ifade ettiği gibi günümüzde eğitim evde, okulda, iște, sokakta heryerde sürdürülen bir etkinliktir. Özellikle teknolojik gelişmelerle ortaya çıkan internet, yazılı-görsel basın, televizyonlar, radyolar eğitimi hızla zaman ve mekandan bağımsız kılmakta ve öğrenmeyi okul dışına da taşımaktadır. Program geliştirme uzmanları da değerlerin örtük olarak kazanıldığı bu yolları ihmal etmemeli ve örtük program dahilinde planlayabilmelidir.

Araştırmanın birinci sorusuna ilişkin dikkati çeken bir diğer bulgu şudur: Hem öğretmenler hem de öğrenciler için kişisel-evrensel değerlerin kazanılmasında örtük program resmi programın önüne geçmiştir. Oysa kişisel değerler bireyin kişiliğinin oluşmasında en etkili değerlerdir. Ültanır'ın (1993) Amerika'da yapılmış boylamsal bir araştırmaya yönelik olarak verdiği bulgular bu düşünceyi destekler niteliktedir. Nitekim bu araștırmada da kişilerin olumlu ve olumsuz tüm davranışlarının sahip oldukları değerlerce şekillendiği vurgulanmaktadır. Bununla birlikte okulların eğitim felsefeleriyle, kurum kültürleriyle, yönetici ve öğretmen davranıșlarıyla değerlerin kazanılmasında ne kadar etkili olabileceğini bulgulayan araştırmalar da bulunmaktadır (Akbaş, 2007; Başar, Akan ve Çankaya, 2014). da. Bu anlamda, resmi programlar kişisel-evrensel değerleri de ulusal değerler gibi ele almalı ve en az onlar kadar etkili verebilmelidir. Araştırmanın ikinci sorusuna ilişkin bulgular Tablo 3'te sunulmuştur.

Tablo 3: Öğretmen ve Öğrenci Görüşlerine Göre Değerleri Kazanma Yollarının Etkililiğine İlişkin Anova Değerleri

\begin{tabular}{|l|l|l|l|l|l|l|}
\hline Varyansın Kaynağı & KT & sd & KO & F & p & $\Gamma^{2}$ \\
\hline Öğretmen-Öğrenci & 8.03 & 1 & 8.03 & 36.34 & .00 & .00 \\
\hline Değer Kazanma Yolları & 38.71 & 4 & 9.67 & 43.78 & .00 & .03 \\
\hline $\begin{array}{l}\text { Değer Kazanma Yolları X Öğretmen- } \\
\text { Öğrenci }\end{array}$ & 7.32 & 4 & 1.83 & 8.28 & .00 & .00 \\
\hline Hata & 986.96 & 4465 & .22 & & & \\
\hline TOPLAM & 25872.30 & 4475 & & & & \\
\hline
\end{tabular}

KT: Kareler toplamı KO: Kareler ortalaması

Tablo 3'ten de inceleneceği gibi değerleri kazanma yollarının etkililiği öğretmenöğrenci görüşüne göre $(F(1-4465)=36.34, p=0.00, p<0.05)$ ve değerlerin kazanıldığı yola göre $(\mathrm{F}(4-4465)=43.78, \mathrm{p}=0.00, \mathrm{p}<0.05)$ anlamlı farklılıklar göstermiştir. Ayrıca, öğretmen-öğrenci görüşlerinin ve değer kazanma yollarının değerlerin kazanılma etkililiği üzerindeki ortak etkisi de anlamlı bulunmuştur $(F(4-4465)=8.28, p=0.00$, $\mathrm{p}<0.05)$. Öğretmen ve öğrenci görüşleri arasındaki farkın incelenmesi için grup sayısı 
üçten az olduğundan post hoc yapılamamıș, t testi yapılmıştır. Yapılan t-testi sonucunda değer kazanma yollarının etkililiğine ilişkin öğrenci ve öğretmen görüşleri arasında, öğrenciler lehine anlamlı bir fark bulunmuştur ( $\mathrm{t}=0.86, \mathrm{p}=0.00, \mathrm{p}<0.05)$. Farka ilişkin çizgi grafiği Şekil 2'de sunulmuştur.
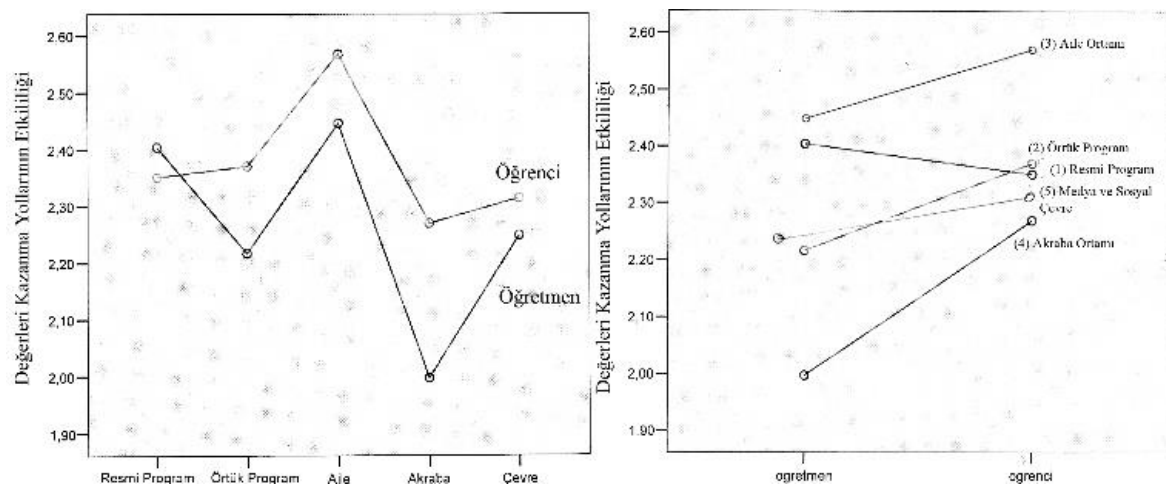

Şekil 2: Değerleri Kazanma Yollarının Etkililiğine İlişkin Öğretmen ve Öğrenci Görüşleri

Şekil 2'den de inceleneceği gibi değerleri kazanma yollarının etkililiğine yönelik öğretmen ve öğrenci görüşleri farklılaşmıştır. Yolların etkililiği öğrenciler için aile ortamı, örtük program, resmi program, medya-sosyal çevre, akraba ortamı șeklinde sıralanırken; öğretmenler için bu sıra aile ortamı, resmi program, medya-sosyal çevre, örtük program, akraba ortamı şeklinde değişmiştir.

Araştırmanın ikinci sorusuna ilişkin dikkati çeken ilk bulgu şudur: Aile ortamı hem öğretmenlerin hem de öğrencilerin görüșleriyle değerlerin kazanılmasında en etkili yol olarak belirlenmiştir. Erden (2005) sosyalleşme sürecinin ilk olarak ailede başladığını, ailelerin sahip oldukları değerleri ve bağlı oldukları alt kültürün özelliklerini çocuklara benimsettiklerini ifade eder. Benzer şekilde Doğan (2007), ailedeki norm ve değerlerin günlük yaşamla birlikte ahlaki, hukuki ve siyasi yaşantıların tümünü belirlediğini dolayısıyla aile kültürünün toplumsal kültüre de yön verdiğini belirtir. $\mathrm{Bu}$ nedenle program geliștirme etkinlikleri düzenlenirken aile birliğinin rolü ve önemi unutulmamalıdır. Ailelerin bilinçli davranabilmelerini ve değerlerin kazanılması sürecinde çocuklarına doğru rehber olabilmelerini sağlayacak tedbirler alınmalıdır.

Araştırmanın ikinci sorusuna ilişkin bir diğer bulgu şudur: Akraba ortamı, hem öğretmenlerin hem de öğrencilerin görüşlerine göre değerlerin kazanılmasında diğer yollara nazaran en düşük etkililiğe sahiptir. Doğan'ın (2007) da ifade ettiği gibi değişen toplumun öngördüğü koşullar karşısında geleneksel değerler insiyatif kaybetmektedir. Geleneksel toplum çekirdek aileye doğru çözülmektedir. Dikkati çeken bir diğer nokta hem öğretmenlerin hem de öğrencilerin görüşlerine göre medyanın akraba ilişkilerinden daha etkili olduğunun tespit edilmesidir. Bu durumda medyanın, toplumsal değişimin bir sonucu olarak gittikçe zayıflayan akraba ilişkilerinin yerini aldığı düşünülebilir. Önür'ün (2007) de ifade ettiği gibi medya, kültür ekimiyle etkin yönlendirme gücünü kaybetmiş değerler üzerinde etkili olmaktadır. Burada dikkat edilmesi gereken bir diğer nokta şudur; araştırmayla değerlerin kazanılmasında en etkili etmen olarak belirlenen aile de medyanın etkisine maruz kalmaktadır.

Araştırmanın ikinci sorusuna ilişkin dikkat çekici bir diğer bulgu şudur: Değerlerin kazanılmasında örtük programın öğrencilere göre resmi programdan daha etkili olduğu; resmi programın ise öğretmenlere göre örtük programdan daha etkili olduğu 
saptanmıştır. Araștırmanın literatür tarama sürecinde öğretim programlarının incelenmesi sonucunda kişisel-evrensel, ulusal değerlere yeterince yer verildiği görülmüştür. Buna rağmen öğrencilerin görüşü, resmi programın değerlerin kazanılmasında yeterince etkili olmadığı yönündedir. Zıt biçimde öğretmenler, resmi programın değerlerin kazanılmasında yeterince etkili olduğunu ifade etmiștir. Öğretmen ve öğrenci görüşü arasında ortaya çıkan bu farklılığın, öğretmenlerin verdikleri derslerin öğretim programında yer alan değerlere yeterince vakıf olmamalarından dolayısıyla derslerde bu değerlere ulaşma yönünde yeterince çaba harcamadıklarından kaynaklandığı düşünülmektedir. Demir (2007) tarafından yapılan araştırmanın bulgusu da bu görüşü destekler niteliktedir. 2005 öğretim programlarına yönelik öğretmen görüşlerinin değerlendirildiği bu araştırmada, örneklemi oluşturan öğretmenlerin yarısının programın yalnızca derslerinde gereken kısımlarını inceledikleri, bir kısmının ise programı çok az inceledikleri tespit edilmiştir. Ne yazık ki, bu araștırmaya katılan öğretmenlerin de sadece dörtte biri öğretim programlarının tamamını incelediğini belirtmiş; öğretim programlarında yer alan değerlerin tamamını inceleyen öğretmenlerin oranının ise sadece bește bir olduğu belirlenmiștir. Öğretmenlerin değerlere ve örtük programa yönelik hakimiyetlerinin düşük olması örtük programın rastlantısal olarak işlemesine ve bu yolla istenilmeyen değerlerin kazanılmasına sebep olabilir. Oysa değerler istikrarlı bir biçimde her ünitede veya her derste verilmeli, örtük program da bir değer kazanma aracı olarak planlanıp, kullanılabilmelidir. Akbaş'ın (2007) da ifade ettiği gibi değer eğitimi vermek ayrı bir ders açmak anlamına gelmemelidir. Çünkü değerler, her konu alanına planlı bir şekilde kaynaştırılabilir, farklı bir ifadeyle örtük programdan faydalanılarak değerlerin kazanılması sağlanabilir.

Araştırmanın bulguları göz önüne alındığında devam eden araştırmalara yön verebilecek öneriler şu şekilde ifade edilebilir:

1. Değerlerin kazanılmasında öğretmenler resmi programın, öğrenciler ise örtük programın daha etkili olduğunu ifade etmişlerdir. Sonraki araştırmalar bu görüş farkının nedenine odaklanabilir.

2. Bu araştırmada değerlerin örtük olarak kazanılmasında etkili olan yollar belirlenmiștir. Sonraki araștırmalar bu yolların değerlerin kazanılmasında nasıl planlanabileceğini konu alabilir.

3. Bu araştırma 1-8. sınıflarda yürütülmüştür. Sonraki araştırmalar farklı okul türlerinde ve farklı öğrenim kademelerinde gerçekleştirilebilir.

Araştırmanın bulguları göz önüne alındığında uygulayıcılara yön verebilecek öneriler şu şekilde ifade edilebilir:

1. Program geliştirme uzmanları örtük öğrenmeleri örtük program kapsamında, değerlerin kazanıldığı okul içi ve okul dışı yolları da hesaba katarak, resmi programı destekleyecek şekilde planlayabilir.

2. Öğretmenlere örtük öğrenmelere ve değerler eğitimine yönelik hizmet içi eğitim verilebilir.

3. Aileler değerlerin kazanılması sürecindeki görevlerine ilişkin bilinçlendirilebilir.

\section{KAYNAKÇA}

ADIAY, S. (2011). Başarı düzeyleri farklı ilköğretim 7. sınıf ortamlarının örtük programın sınıf iklimi boyutu açısından incelenmesi (Yayımlanmamış Yüksek Lisans Tezi). Sakarya Üniversitesi Eğitim Bilimleri Enstitüsü, Sakarya. 
AHOLA, S. (2000). Hidden curriculum in higher education: Something to fear for or comply to. Erișim tarihi: 07.08.2018.

AKBAȘ, O. (2007). Değerler ve Eğitimi Uluslararası Sempozyumu. Türk milli eğitim sisteminin duyuşsal amaçlarının (değerlerinin) ilköğretim 8. sınıf öğrencilerinde gerçekleşme derecesinin değerlendirilmesi (ss. 676). İstanbul: DEM Yayınları.

AKBULUT, E. (2011). Illköğretim okullarında örtük program faaliyetlerinin saptanması (Yayımlanmamış Yüksek Lisans Tezi). İnönü Üniversitesi Eğitim Bilimleri Enstitüsü, Malatya.

AKBULUT, N. (2016). Üniversite öğrencilerin örtük program algılama düzeyleri ile eğitim stresi algılama düzeyleri arasındaki ilişkinin incelenmesi (Yayımlanmamış Yüksek Lisans Tezi). Sakarya Üniversitesi Eğitim Bilimleri Enstitüsü, Sakarya.

AKÇAKOCA, B. (2018). Hemşirelik eğitiminde örtük programı değerlendirmede kullanılacak bir ölçme aracı geliştirme çalışması (Yayımlanmamış Yüksek Lisans Tezi). Ege Üniversitesi Sağlık Bilimleri Enstitüsü, İzmir.

AKTAŞ, H.H. (2016). Students' views about and experiences at school: Investigating the role of cultural capital and hidden curriculum (Yayımlanmamış Yüksek Lisans Tezi). Ortadoğu Teknik Üniversitesi Sosyal Bilimler Enstitüsü, Ankara.

ALTUNIŞIK, R., COŞKUN, R., BAYRAKTAROĞLU, S., YILDIRIM, E. (2005). Sosyal bilimlerde araștırma yöntemleri spss uygulamalı. İstanbul: Sakarya Kitabevi.

ANYON, J. (1984). Intersections of gender and class: accommodation and resistance by working class and affluent females to contradictory sex-role ideologies. Journal of Education. Cilt 166 (1), 25-48. doi:10.1177/002205748416600104

APPLE, W. M. (2012). Education and power (Gözden geçirilmiş 2. baskı). New York: Routledge.

ARIKAN, A. (09.07.2004). Gizli müfredatı öğrenci deneyimleri yoluyla ortaya çıkarmak. Erişim tarihi: 07.08.2018, https://www.pegem.net/dosyalar/dokuman/337.pdf

AYDENIZ, N. (2017). Ortaöğretim din kültürü ve ahlak bilgisi dersinin örtük program açısından incelenmesi (Yayımlanmamıș Doktora Tezi). Sakarya Üniversitesi Eğitim Bilimleri Enstitüsü, Sakarya.

BACANLI, H. (2006). Duyuşsal davranış eğitimi, Ankara: Nobel Yayın Dağıtım.

BAĞLI, M.T., \& ESEN, Y. (2002). İlköğretim ders kitaplarındaki kadın ve erkek resimlerine ilișkin bir inceleme, Ankara Üniversitesi Eğitim Bilimleri Fakültesi Dergisi, Cilt 35 (1-2), 143-154. doi: 10.1501/0000769

BARBOUR, C.H., ROBERTS-KING, H., STITES, M.L., SCULLY, P. (2018). Families, schools and comminities: building partnerships for educating children. USA: Pearson.

BAȘAR, M. (2011). Sınıf içi istenmeyen öğrenci davranışlarının yönetiminde örtük program (Yayımlanmamış Doktora Tezi). Marmara Üniversitesi Eğitim Bilimleri Enstitüsü, İstanbul.

BAŞAR, M., AKAN, D., ÇANKAYA, İ. (2014). Örtük program çerçevesinde okul yöneticilerinin yönetsel uygulamalarının değerlendirilmesi. Erzincan Üniversitesi Eğitim Fakültesi Dergisi, 16 (1), 239-263. doi: 10.17556/jef.75036

BAYDILEK, N.B. (2013). Okul öncesi eğitim programında akıl yürütme becerilerinin yeri ve okul öncesi eğitim sınıflarında akıl yürütme becerilerinin desteklenmesinde örtük programın işlevi (Yayımlanmamıș Doktora Tezi). Adnan Menderes Üniversitesi Sosyal Bilimler Enstitüsü, Aydın.

BOWLES, S., GINTIS, H. (2011). Schooling in capitalist America: educational reform and the contradictions of economic life. Chicago: Haymarket Books.

BOZTAŞ, K. (2015). Tutum ve değerler kapsamında polis meslek yüksekokulu örtük programı (Yayımlanmamış Doktora Tezi). Balıkesir Üniversitesi Sosyal Bilimler Enstitüsü, Balıkesir. 
BÜYÜKÖZTÜRK, Ş. (2018). Sosyal bilimler için veri analizi el kitabı. Ankara: Pegema Yayıncılık.

CASTELLO, C. Y. (2001). Schooled by the classroom the (re) production of social stratification in professional school settings. The Hidden Curriculum in Higher Education (ss.43). New York: Routledge.

CEVIZCI, A. (2008). Etiğe giriş. İstanbul: Paradigma Yayıncılık.

ÇENGEL, M. (2013). Sınıf ikliminin oluşması sürecinde örtük program: Meslek liseleri üzerine bir araștırma (Yayımlanmamıș Doktora Tezi). Adnan Menderes Üniversitesi Sosyal Bilimler Enstitüsü, Aydın.

ÇINAR, İ. (03.07.2003). Eğitimde Atatürkçülük ve örtük program. Erişim tarihi: 18.06.2018, http://www.egitisim.gen.tr/tr/index.php/arsiv/sayi-1-10/sayi-3-ataturktemmuz-2003.

DEMIR, M. (2013). Eğitimci olmayan hizmetli personelin örtük program çerçevesinde öğrencilerin duyuşsal gelişimine olan etkisinin incelenmesi (Yayımlanmamıș Yüksek Lisans Tezi). Kilis 7 Aralık Üniversitesi Sosyal Bilimler Enstitüsü, Kilis.

DEMIR, M. (2018). Sosyal medya üzerinden gerçekleșen öğretmen-öğrenci etkileșiminin örtük program açısından incelenmesi (Yayımlanmamıș Doktora Tezi). İnönü Üniversitesi Eğitim Bilimleri Enstitüsü, Malatya.

DEMIR, S. (2007). İlköğretim okullarında görev yapan 1., 2., 3., 4. ve 5. sinıf öğretmenlerinin 2005 öğretim programlarına ilişskin görüşleri (Yayımlanmamış Yüksek Lisans Tezi). Yıldız Teknik Üniversitesi Sosyal Bilimler Enstitüsü, İstanbul.

DOĞANAY, A. \& SARI, M. (2006). Öğrencilerin üniversitedeki yaşam kalitesine iliş̧in algılarının demokratik yaşam kültürü çerçevesinde değerlendirilmesi (Çukurova üniversitesi örneği), Türk Ĕgitim Bilimleri Dergisi, Cilt (4), 107-128.

DOĞAN, İ. (2007). Türk eğitim sisteminde değer sorunu. Değerler ve Eğitimi Uluslararası Sempozyumu (ss.615). İstanbul: DEM Yayınları.

DOLL, R. (1995). Curriculum improvement decision making and process. USA: Pearson Education.

DREEBEN, R. (2002). On what is learned in school. USA: Eliot Werner Publications Inc.

ELDELEKLİĞGLU, J. (1999). Karar stratejileriyle ana-baba tutumları arasındaki ilişki. Türk Psikolojik Danışma ve Rehberlik Dergisi. Cilt 2 (11), 293-304.

ERDEM, A.R. (01.12.2006). Türkiye'nin önemli sorunlarından biri: yetiştirdiği insan tipi. Erişim tarihi: 2 Mart 2009.

http://www.universitetoplum.org/pdf/pdf.php?id=292.

ERDEN, M. (2005). Öğretmenlik mesleğine giriş. İstanbul: Epsilon Yayınları.

ERDOĞAN, İ. (2008). Öğrenmenin gücü, İstanbul: Alfa Yayınları.

EVIN, İ., KAFADAR, O. (2004). İlköğretim sosyal bilgiler programının ve ders kitaplarının ulusal ve evrensel değerler yönünden içerik çözümlemesi. Türk Eğitim Bilimleri Dergisi. Cilt 2 (3), 293-304.

FIDAN, M. (2013). Ortaokullarda Bilişim Teknolojileri dersinde örtük programın varlı̆̆ına ilişkin öğretmen görüşleri: Bolu ili örneği (Yayımlanmamıș Yüksek Lisans Tezi). Abant İzzet Baysal Üniversitesi Eğitim Bilimleri Enstitüsü, Aydın.

FILIZ, B. (2011). Malatya ili Merkez ilçesi devlet ilköğretim okullarında öğrenim gören ilköğretim 7. sınıf öğrencilerinin düşüncelerine dayalı olarak beden eğitimi öğretmenlerinin örtük programı uygulama durumlarının tespiti (Yayımlanmamış Yüksek Lisans Tezi). İnönü Üniversitesi Eğitim Bilimleri Enstitüsü, Malatya.

GAIR, M., MULLINS, G. (2001). Hiding in Plain Sight. The Hidden Curriculum In Higher Education (ss.21). New York: Ruthledge.

GARDNER, H. (2006). Eğitimli akıl: olayların ve standart testlerin ötesinde her çocuğun hak ettiği K-12 eğitimi. (Ö. Akbaş, Çev.) İstanbul: Morpa Yayınları. 
GIRAYHAN, S. (2019). Üniversite yerleșkelerinin kalite yaklaşımları ve örtük program açısından değerlendirilmesi (Gazi Üniversitesi örneği) (Yayımlanmamış Yüksek Lisans Tezi). Gazi Üniversitesi Eğitim Bilimleri Enstitüsü, Ankara.

GIROUX, A.H. (2001). Theory and resistance in education: towards a pedagogy for the opposition revised and expanded edition (Gözden geçirilmiş 2. baskı). USA: Westport.

GÜN, M. (2018). Türk Hava Kuvvetleri Subay ve Astsubay Yetiştirme Okulu örtük program kapsamının okul iklimi ve sınıf iklimi boyutlarıly incelenmesi (Yayımlanmamış Yüksek Lisans Tezi). Balıkesir Üniversitesi Sosyal Bilimler Enstitüsü, Balıkesir.

HELVACIOĞLU, F. (1994). 1928'den 1994'e ders kitaplarında cinsiyetçilik (Yayımlanmamış Yüksek Lisans Tezi). İstanbul Üniveristesi, Sosyal Bilimler Enstitüsü, İstanbul.

HEMMINGS, A. (2000). The hidden corridor curriculum. The High School Journal, Cilt 83 (2), 1-10.

İlköğretim Genel Müdürlüğü (IOGM). (2005). İlköğretim programları. Erişim tarihi: 17.01.2009, http://mufredat.meb.gov.tr/Programlar.aspx.

İlköğretim Genel Müdürlüğü (IOGM). (2018). İlköğretim programları. Erişim tarihi: 18.06.2018, http://mufredat.meb.gov.tr/Programlar.aspx.

JACKSON, P.W. (1991). Life in classrooms. (Gözden geçirilmiş 2. baskı). USA: Teachers' College Press.

KALE, N. (2004). Etik sorunsallar ve eğitim. Ankara: Seçkin Yayıncılık.

KARASAR, Niyazi. 2005. Araştırmalarda rapor hazırlama. (13. Baskı). Ankara: Nobel Yayınevi.

KAVAK, N., TUFAN, Y. \& DEMIRELLI, H. (2006). Fen-teknoloji okuryazarlığı ve informal fen eğitimi, Gazi Ĕgitim Fakültesi Dergisi, Cilt 26 (3), 17-28.

KESICI, A.E. (2010). Ortaöğretim öğretmenlerinin sınıf içi iletişimde kullandıkları örtük programın özellikleri (Yayımlanmamış Doktora Tezi). Adnan Menderes Üniversitesi Sosyal Bilimler Enstitüsü, Aydın.

KOYUNCU, M. (2019). Anadolu imam hatip liselerinde örtük programın tespiti (Konya ili örneği) (Yayımlanmamış Yüksek Lisans Tezi). İnönü Üniversitesi Sosyal Bilimler Enstitüsü, Malatya.

KUŞ, D. (2009). İlköğretim programlarinin, örtük programın ve okul dışl etmenlerin değerleri kazandırma etkililiğinin 8. sınıf ilköğretim öğrencilerinin ve öğretmenlerinin görüşlerine göre incelenmesi (Yayımlanmamış Yüksek Lisans Tezi). Yıldız Teknik Üniversitesi Sosyal Bilimler Enstitüsü, İstanbul.

LEMPP, H., SEALE, C. (2004). The hidden curriculum in undergraduate medical education: qualitative study of medical students' perceptions of teaching. BMJ Online. Cilt 329 (3), 770-773.

LYNCH, K. (1989). The hidden curriculum: reproduction in education. London: The Farmer Press.

ORNSTEIN, A.C., HUNKINS, F. P. (2017) Curriculum: foundations, principles and issues, Boston: Allyn and Bacon.

ÖNÜR, N. (2007). Modernleşme Sürecinde Okul Aile ve Medya Kavșağında Değerler. Değerler ve Eğitimi Uluslararası Sempozyumu (ss.157). İstanbul: DEM Yayınları. ÖZASLAN, D. (2019). Eğitim fakültesi öğrencilerinin örtük program algılarının incelenmesi. (Yayımlanmamış Yüksek Lisans Tezi). Kahramanmaraş Sütçü İmam Üniversitesi Sosyal Bilimler Enstitüsü, Kahramanmaraș.

SALDIRAY, A. (2017). Örtük programda toplumsal cinsiyet: Bir ilkokulun örtük programında toplumsal cinsiyete iliş̧kin nitel bir çalışma (Yayımlanmamış Yüksek Lisans Tezi). Çukurova Üniversitesi Sosyal Enstitüsü, Adana. 
SAMBELL, K., MCDOWELL, L. (1998, Aralık). The construction of the hidden curriculum: messages and meanings in the assessment of student learning. Assessment and Evaluation in Higher Education. Cilt 23 (4), 391-402. doi: 10.1080/0260293980230406

SARI, M. (2007). Demokratik değerlerin kazanımı sürecinde örtük program: düşük ve yüksek okul yaşam kalitesi'ne sahip iki ilköğretim okulunda nitel bir çalışma (Yayımlanmamıș Doktora Tezi), Çukurova Üniversitesi Sosyal Bilimler Enstitüsü, Adana.

SERHATLIOĞLU, B. (2012). Sosyal becerilerin kazanımı sürecinde örtük programın işlevi (Yayımlanmamış Doktora Tezi). Fırat Üniversitesi Eğitim Bilimleri Enstitüsü, Elazığ.

SEZEN, Ö. (2011). A case study on the hidden curriculum of a university foreign languages preparatory school through perceptions (Yayımlanmamış Yüksek Lisans Tezi). Marmara Üniversitesi Eğitim Bilimleri Enstitüsü, İstanbul.

SMITH, M.C, SMITH, T.J. (2008). Low-education adults' participation in informal learning activities: relationships with selected demographic characteristics. Adult Basic Education and Literacy Journal, Cilt 2 (2), 67-73.

SÖNMEZ, V. (2008). Eğitim felsefesi. Ankara: Anı Yayıncılık.

ŞENCAN, H. (2005). Sosyal ve davranışsal ölçümlerde güvenilirlik ve geçerlilik. Ankara: Seçkin Yayıncılık.

ŞEN, Ü. (2008, Kasım). Altıncı sınıf Türkçe ders kitaplarındaki metinlerin ilettiği değerler açısından incelenmesi. The Journal of International Social Research, Cilt 1 (5), 763-779.

TANRIVERDI, M. (2017). Mesleki ve Teknik Anadolu Liselerinin örtük program kapsamının belirlenmesi (Yayımlanmamıș Doktora Tezi). Balıkesir Üniversitesi Sosyal Bilimler Enstitüsü, Balıkesir.

ŞENYÜKSEL, M. (2019). Toplumsal cinsiyet ve örtük program bağlamında öğretmen görüşleri (Yayımlanmamış Yüksek Lisans Tezi). Dokuz Eylül Üniversitesi Sosyal Bilimler Enstitüsü, İzmir.

TEMIZ, N. (2007). The evaluation of the 'sitcom sihirli annem' in terms of 'curriculum evaluation, Eurasian Journal of Educational Research, Cilt 7 (2), 179-189.

TIETZ, W. M. (2007, Ağustos). Women and men in accountings textbooks: exploring the hidden curriculum. Issues in Accounting Education. Cilt 22 (3), 459-480.

TOR, D. (2015). Exploring physical environment as hidden curriculum in higher education: A grounded theory study (Yayımlanmamış Doktora Tezi). Ortadoğu Teknik Üniversitesi Sosyal Bilimler Enstitüsü, Ankara.

TUNALI, İ. (2008). Estetik. İstanbul: Remzi Kitabevi.

ULUSOY, K. (2007). Lise tarih programlarında yer alan geleneksel ve demokratik değerlere yönelik öğrenci tutumlarının ve görüşlerinin çeşitli değişkenler açısından incelenmesi (Yayımlanmamıș Doktora Tezi). Gazi Üniversitesi Eğitim Bilimleri Enstitüsü, Ankara.

ÜLTANIR, E. (2003). İlköğretim birinci kademe rehberlik ve danışma. Ankara: Nobel Yayın Dağıtım.

WREN, J.D. (1999). School culture: exploring the hidden curriculum. Adolescence, Cilt 34 (135), 593-596.

YILDIRIM, B. (2015). Sinıf öğretmenlerinin örtük program kavramına ilişskin algıları (Yayımlanmamış Yüksek Lisans Tezi). Cumhuriyet Üniversitesi, Eğitim Bilimleri Enstitüsü, Sivas.

YILDIRIM, C. (2018). Ortaöğretim öğrencilerinin demokratik vatandaşlık tutumlarının resmi ve örtük program açısından incelenmesi (Yayımlanmamış Doktora Tezi). Adnan Menderes Üniversitesi Sosyal Bilimler Enstitüsü, Aydın. 
YILDIRIM, F. (2013). Illköğretim okullarında örtük program ve ilköğretim öğrencilerinin örtük programdan kaynaklanan stres algıları (Yayımlanmamış Doktora Tezi). Fırat Üniversitesi Eğitim Bilimleri Enstitüsü, Elazı̆̆.

YÜKSEL, S. (2004). Örtük program: eğitimde saklı uygulamalar. Ankara: Nobel Yayın Dağıtım.

ZIEBERTZ, G.H. (2007). Çok kültürlü bir toplumda değerler eğitimi modelleri. Değerler ve Eğitimi Uluslararası Sempozyumu (ss.445). İstanbul: DEM Yayınları.

\section{Summary}

Education is not only an activity restricted by course hours. Educational institutions' philosophies, culture, institutional arrangements, opportunities, relations with environment are important parts of education although they are not included in education plan. In addition to this, learning goes on as an hidden activity not only at school but also in family, social circle, virtual environment, military, street, and mosque. Most of the time values that are gotten in this way have become more permanent. Therefore adding values to curricula only in paper as a course gain does not mean learning of values. It is needed to be a follower of which values, in which way and how much can be gained. This research asks for an answer from teachers and students to the question "what is the effectiveness of school curricula, hidden curriculum and out of school sources in gaining values?" basing on prior opinion. Values that are aimed to be added to 2005 Primary School Curricula among compulsory courses and be gained have been determined and gaining effectiveness by curricula, hidden curriculum and out of school sources of these values have been examined in the direction of teacher's and student's opinions. Curricula, hidden curriculum and out of school sources have been classified as their way of gaining value and effectiveness of these ways in gaining values have been examined according to teacher's and student's opinions.

Opinions of 155 teachers and 740 students who joined the search are collected with the Ways of Gaining Values in Primary School Curricula Survey developed by Seval Fer and Derya Kus. Draft of the survey has been examined by eight subject matter experts, seven of whom were YTU academic members and has been changed considering the changes offered by at least five of them. A pilot scheme has been made with ten students and fifteen teachers for the comprehensibility test of the survey, and validity and reliability tests have been made from the results of the main scheme. Seven factors have been determined in both surveys under the two main dimensions questioning which values are gained in what ways. In the first dimension, values in 2005 Primary School Curriculas have been examined under two factors as "personal-universal, national values"; in the second dimension, the ways these values are gained have been examined under five factors as "curricula, hidden curriculum, family setting, relative setting, media-social environment" according to students' and teachers' opinions. For the analysis of the data in the first dimension Manova technique, for the analysis of the data in the second dimension Anova technique is used.

Results of the research are as the following: 1) Out of school factors have been determined to be the most effective factor in gaining personal-universal and national values according to opinions of both teachers and students. According to this, education is in the activities out of the school building, both teacher and student are aware of this. 2) It has been determined that hidden curriculum gets ahead of the curricula in gaining personaluniversal values. Yet personal values are the most effective values in personality formation. In this sense, curriculas must deal with personal-universal values like they deal with national values, and must be as effective as they are in national values. 3) Effectiveness of ways of gaining values out of school has been determined according to opinions of teachers and 

Etkililiğinin İncelenmesi”, İstanbul Gelişim Üniversitesi Sosyal Bilimler Dergisi, 7 (2), Ekim 2020, ss. 404-420.

students as family setting, media-social environment and relative setting. At this stage, it can be thought that the most effective way in gaining values is family setting and media is taking the place of gradually weakening relative relationships as a result of social change. However the noteworthy point is that family is also exposed to effect of the media. 4) It has been stated that according to students hidden curriculum is more effective than curricula; according to teachers curricula is more effective than hidden curriculum in gaining values. It has been thought that the difference between teachers' and students' opinions take its source from the fact that teacher's lessons don't have a grasp of the values partaking in curricula so teachers don't effort to reach these values in their lessons. Thus, it has been stated that only one fourth of teachers examines the complete curricula; and the rate of teachers who examines the values partaking in curricula is only one fifth. 